\title{
INHERITANCE OF SEED SIZE IN COWPEA (VIGNA UNGUICULATA (L.) WALP.)
}

\author{
I. DRABO ${ }^{1}$, R. REDDEN ${ }^{2}$, J. B. SMITHSON ${ }^{3,4}$ and V. D. AGGARWAL ${ }^{1}$ \\ International Institute of Tropical Agriculture-IITA, Ibadan, Nigeria
}

Received 12 March 1984

INDEX WORDS

Vigna unguiculata, cowpea, seed size, genetics, additive, dominance, heritability

SUMMARY

The inheritance of seed weight in cowpea was examined in a field planting of the parents, reciprocal $F_{1} s$, $\mathrm{F}_{2} \mathrm{~s}$ and backcrosses to both parents of a cross between TVu 1977-OD (small seeded) and ACC 70002 (large).

Seed weight was inherited quantitatively and small seed was partially domiminant to large seed size. Gene action was predominantly additive but dominance and additive $\times$ additive epistatic effects were also significant.

Broad and narrow sense heritabilities were $85.1 \pm 5.3 \%$ and $75.4 \pm 18.6 \%$ respectively. The minimum number of loci involved in the inheritance of seed size was eight, and each gene pair contributed up to $1.02 \mathrm{~g}$ increase to seed weight. The estimate of genetic advance from $\mathrm{F}_{2}$ to $\mathrm{F}_{3}$ generations with $5 \%$ selection intensity was $3.58 \mathrm{~g}$.

\section{INTRODUCTION}

Seed size is an important characteristic of cowpea in West Africa where seeds of most of the cultivars preferred and grown by farmers are large and white or brown with a rough testa.

Genetic investigations of seed size have given contradictory results with regard to the relative importance of additive and dominance effects in its inheritance and the number of genes controlling the character. BRITTINGHAM (1950) reported heterosis for seed size and transgressive segregation for large seed. Heterosis for seed size was also reported by AGBLE (1972) who concluded that gene action determining seed size may not be additive. SENE (1968) found that seed weight was controlled by six pairs of genes acting additively and that each gene corresponded to a weight increase of $1.1 \mathrm{~g}$. ARYEETEY \& LAING (1973) concluded that this character was controlled by ten pairs of genes. DraBo et al. (unpublished) found that additive, dominance and epistasics effects were present in the inheritance of seed size and that additive gene effects

\footnotetext{
${ }^{1}$ International Institute of Tropical Agriculture, Semi-Arid Food Grain Research and Development Project/National Cowpea Improvement Program, B.P. 1783, Ouagadougou, Upper Volta.

${ }^{2}$ Department of Primary Industries, Hermitage Research Station, Warwick 4370, Queensland, Australia.

${ }^{3}$ International Crops Research Institute for the Semi-Arid Tropics (ICRISAT), ICRISAT Center, Patancheru, P.O. 502 324, A.P., India.

${ }^{4}$ Present address: 5 Byemoor Avenue, Great Ayton, Middlesbrough, Cleveland County, England.
} 
Table 1. Mean seed weights ( $g / 100$ seeds) of reciprocal $F_{1}, F_{2}$, and BC generations of a cross of TVu 1977-OD $\left(\mathrm{P}_{\mathrm{S}}\right)$ and $\mathrm{ACC} 70002\left(\mathrm{P}_{\mathrm{L}}\right)$.

\begin{tabular}{llcll}
\hline Generation & $\begin{array}{l}\text { Female parent } \\
\text { of first cross }\end{array}$ & $\begin{array}{l}\text { Number of } \\
\text { plants }\end{array}$ & Mean & S.E. $( \pm)$ \\
$\mathrm{F}_{1}$ & $\mathrm{P}_{\mathrm{S}}$ & 40 & 16.9 & \\
$\mathrm{~F}_{1}$ & $\mathrm{P}_{\mathrm{L}}$ & 40 & 16.3 & 0.20 \\
$\mathrm{~F}_{2}$ & $\mathrm{P}_{\mathrm{S}}$ & 128 & 14.6 & 0.11 \\
$\mathrm{~F}_{2}$ & $\mathrm{P}_{\mathrm{L}}$ & 128 & 14.7 & 0.23 \\
$\mathrm{BC}_{\mathrm{S}}$ & $\mathrm{P}_{\mathrm{S}}$ & 80 & 12.0 & 0.23 \\
$\mathrm{BC}_{\mathrm{S}}$ & $\mathrm{P}_{\mathrm{L}}$ & 80 & 12.1 & 0.18 \\
$\mathrm{BC}_{\mathrm{L}}$ & $\mathrm{P}_{\mathrm{S}}$ & 80 & 20.0 & 0.22 \\
$\mathrm{BC}_{\mathrm{L}}$ & $\mathrm{P}_{\mathrm{L}}$ & 80 & 19.8 & 0.22 \\
\hline
\end{tabular}

were greater in magnitude than other gene actions. The authors also concluded that large was dominant to small seed size. Conversely, ARYEETEY \& LAING (1973) and LELEJI (1976) observed dominance of small over large seed size.

Broad and narrow sense heritability estimates of $80 \%$ and $71 \%$ respectively were reported by SENE (1968) for seed size. Corresponding values by ARYEETEY \& LAING (1973) were $63 \%$ and $37.4 \%$. LeLEJ (1976) found broad sense heritability for seed size to range from $49 \%$ to $82 \%$. Corresponding values by DRABO et al. (unpublished) were $48 \%$ to $90.2 \%$.

This paper reports studies of the inheritance of seed size in a cross made to incorporate the large seed of a photosensitive and low yielding cowpea cultivar, typical of the landraces grown throughout the West African savannas, into a high yielding background.

\section{MATERIALS AND METHODS}

The parents were two accessions from the world cowpea germplasm maintained by the International Institute of Tropical Agriculture (IITA), Ibadan, Nigeria: TVu 1977-OD, which originated in Zimbabwe and was described by IITA as VITA-4 and designated $P_{S}(9$ to $10 \mathrm{~g}$ per 100 seeds $)$; and ACC 70002 collected in the Niger Republic and designated $\mathrm{P}_{\mathrm{L}}$ (around $26 \mathrm{~g}$ per 100 seed).

Reciprocal crosses were made in 1978 and seed of the $\mathrm{F}_{2} \mathrm{~s}$ and backcrosses to small $\left(\mathrm{BC}_{\mathrm{S}}\right)$ and large $\left(\mathrm{BC}_{\mathrm{L}}\right)$ seeded parents obtained in 1979. The parents and the reciprocal

Table 2. Genetic variances for seed weight ( $\mathrm{g} / 100$ seeds) in different generations of a cross between $\mathrm{TVu}$ 1977-OD and ACC 70002.

\begin{tabular}{lrl}
\hline Generation & d.f. & Variance \\
& & \\
$\mathrm{P}_{\mathrm{S}}$ & 36 & 0.598 \\
$\mathrm{P}_{\mathrm{L}}$ & 36 & 1.204 \\
$\mathrm{~F}_{1}$ & 72 & 0.573 \\
$\mathrm{~F}_{2}$ & 248 & 5.302 \\
$\mathrm{BC}_{\mathrm{S}}$ & 152 & 2.373 \\
$\mathrm{BC}_{\mathrm{L}}$ & 152 & 4.233 \\
\hline
\end{tabular}


$F_{1}$ and $F_{2}$ and backcross populations were sown in the field on the research farm at IITA in September 1980 in a randomised complete block design with four replicates. The plot sizes were two rows for the parents and $F_{1} s$, four rows for the $F_{2} s$ and three rows for the $\mathrm{BC}$ generations, each of $3 \mathrm{~m}$ length. The planting density was $1 \mathrm{~m}$ between and $30 \mathrm{~cm}$ within rows. The seed weights were recorded for ten random plants from each plot for parents and $F_{1} s, 32$ for $F_{2} s$ and 20 for the backcross generations, and expressed as weight of 100 seeds in grams (all sampled plants had at least 100 seeds).

Generation means were obtained from the averages of plot means. The variances and standard errors of the means for each generation were obtained from the within plot sums of squares (LAWRENCE \& JINKS, 1973). A simple analysis of variance was performed to compare reciprocal $F_{1}, F_{2}$ and backcross generations. A generation means analysis was performed according to MATHER \& JINKS (1971).

MATHER's (1949) ABC scaling test and CAVALLI's (1952) joint scaling test were used to test for the significance of additive and dominance gene effects in the inheritance of seed weight. Generation means were also analysed using the six parameter model of JINKS \& JONES (1958). Narrow and broad sense heritability estimates, and the number of effective factors differentiating the parents were evaluated according to LAWRENCE \& JiNKS (1973). Genetic advance under selection was calculated by the method of ALLARD (1960).

\section{RESULTS AND DISCUSSION}

The differences between the means of the reciprocal crosses were small and non-significant so the reciprocals were pooled for subsequent computations (Table 1). The $F_{1}$ mean was less than the midparent value and the mean of the $F_{2}$ lay between the means of the $F_{1}$ and the small seeded parent. The mean of the backcross to the large seeded parent lay between the $F_{1}$ and its recurrent parent, ACC 70002, and was closer to the $F_{1}$ value than that of the backcross to the small seeded parent, which lay between the means of the $F_{1}$ and $T V u$ 1977-OD. These data conform with the conclusions of ARYEETEY \& LAING (1973) and LELEJI (1976) that small seed is partially dominant.

There was no transgressive segregation for large seed in the $F_{2}$ since no $F_{2}$ plant exceeded the large seeded parent (Fig. 1). From a population of $256 \mathrm{~F}_{2}$ plants no parental types were recovered suggesting that the inheritance of seed weight is controlled by more than 3 genes.

The variance of the $F_{2}$ population (Table 2) was much greater than the variances of the parents and the $F_{1}$ generations in which variation is attributed to environmental effects. The variance of $\mathrm{BC}_{\mathrm{L}}$ was larger than the variance of $\mathrm{BC}_{\mathrm{S}}$. Since twice the variance of the $\mathrm{F}_{2}$ was greater than the sum of the variances of the backcross generations $\left(2 \mathrm{VF}_{2}-\mathrm{VBC}_{\mathrm{S}}-\mathrm{VBC}_{\mathrm{L}}=3.998\right)$, nonadditive gene action is indicated.

MATHER's (1949) scaling test and CAVALLI's (1952) joint scaling test were significantly different from zero (Table 3 ) also suggesting the occurrence of epistasis in the inheritance of seed size. Analysis according to JINKS \& JONES (1958) (Table 3) indicated that the additive (d) and dominance (h) gene effects were significantly different from zero, the magnitude of the additive gene effect being nearly double that of the dominance gene effect. Among the epistatic effects only (i) was significantly different from zero indicating additive $\times$ additive gene action. Therefore it appears that additive 

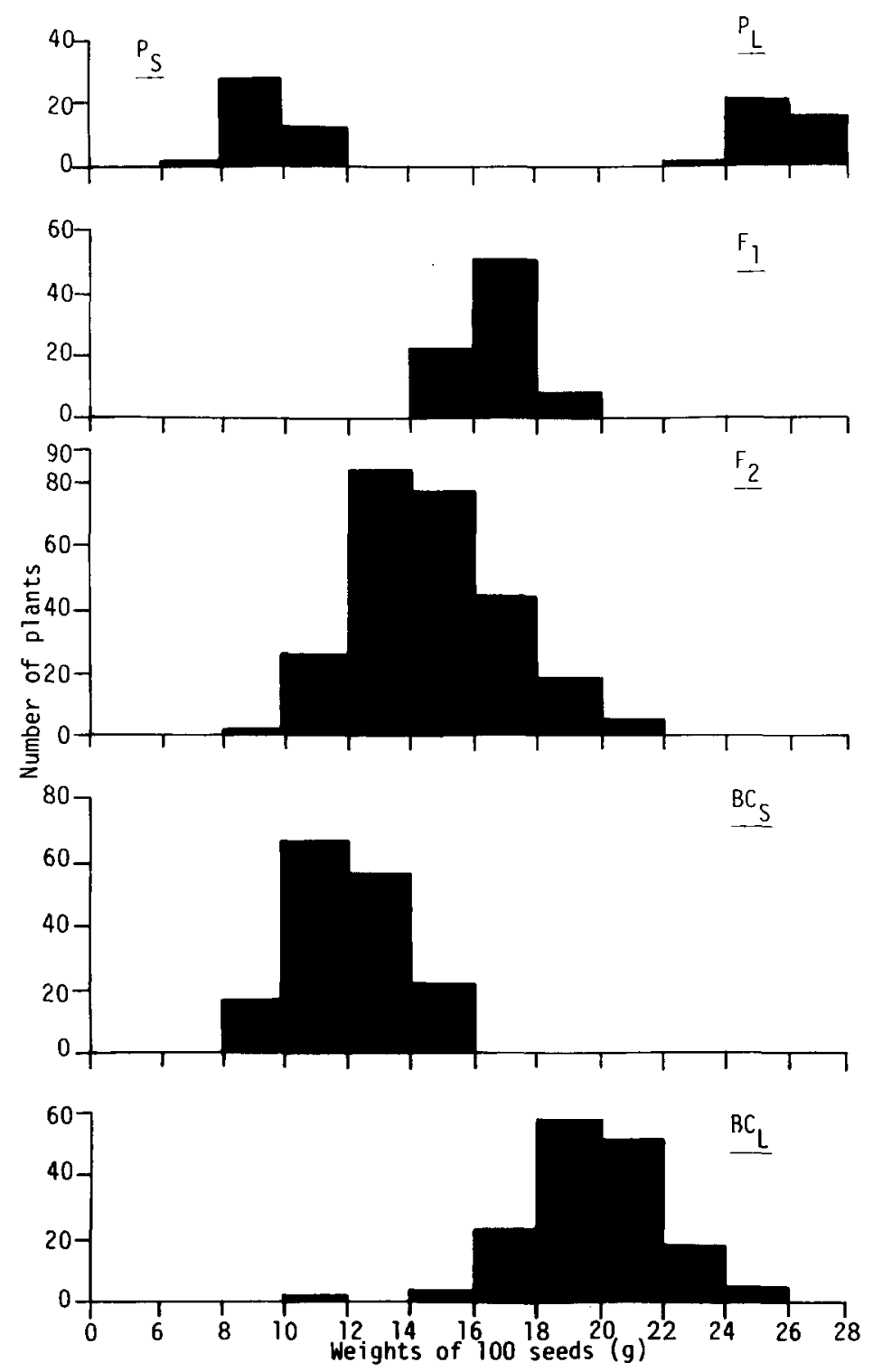

Fig. 1. Frequencies of seed weights of parental $\left(P_{S}\right.$ and $\left.P_{L}\right), F_{1}, F_{2}$ and backcross $\left(B C_{S}\right.$ and $\left.B C_{L}\right)$ generations of the cross of TVu 1977-OD $\left(\mathrm{P}_{\mathrm{S}}\right)$ and $\mathrm{ACC} 70002\left(\mathrm{P}_{\mathrm{L}}\right)$.

and additive $\times$ additive gene actions played a major role in the inheritance of seed size although dominance gene action was also significant. This result is in agreement with SENE (1968) and DRABO et al. (unpublished).

Broad and narrow sense heritability estimates were $85.1 \% \pm 5.3$ and $75.4 \% \pm 18.6$ respectively. This estimate of narrow sense heritability includes both additive and additive $\times$ additive epistatic effects and is therefore an upper limit. Similar results with 
Table 3. Scaling test and gene effects estimated using 3 and 6-parameter models from generation means of a cross between TVu 1977-OD and ACC 70002 .

Model and effect Estimates

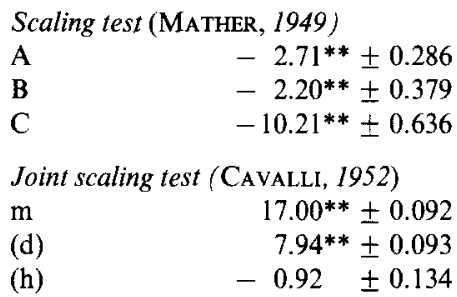

Six-parameter model (JINKS \& JONES, 1959)

$\begin{array}{lr}\text { m } & 12.51^{* *} \pm 0.736 \\ \text { (d) } & 8.14^{* *} \pm 0.212 \\ \text { (h) } & 4.49^{* *} \pm 1.393 \\ \text { (i) } & 5.30^{* *} \pm 0.705 \\ \text { (j) } & -0.51 \pm 0.459 \\ \text { (k) } & -0.40 \pm 1.034\end{array}$

** = Significantly different from zero at 0.01 level of probability.

regard to broad sense heritability were published earlier by SENE (1968), LELEJI (1976) and DraBo et al. (1982).

Assuming that the 5 per cent of $F_{2}$ plants with the largest seeds (18-22 $\mathrm{g}$ ) are selected for further propagation, the expected genetic advance was $3.58 \mathrm{~g}$.

The estimate of $\mathrm{K}$ suggested that a large number of genes (at least eight pairs) control seed size. Although this estimate may be biased by epistasis (WARNER \& HONMA, 1980), it is in agreement with the average number of genes found by SENE (1968) and ARYEETEY \& LAING (1973) who found that seed size was controlled by six and ten pairs of genes respectively. Also each of the proposed eight gene pairs contributed to a $1.02 \mathrm{~g}$ weight increase, which compared well with the $1.1 \mathrm{~g}$ estimated by SENE (1968). However, the qualifying assumptions of equal additive effects at all loci, and complete association of all $(+)$ and $(-)$ genes in the respective large and small seed parents and either absence of linkage or redefinition of a gene as an effective factor of linked genes (LAWRENCE \& JINKS, 1973), indicate that estimates of K are at best only a useful guide to the genetic basis of seed weight.

The study indicated that seed weight is governed by several genes acting mainly additively. The high narrow sense heritability estimate indicates that progress would be expected with early generation selection for large seed size.

\section{REFERENCES}

AGBLE, F., 1972. Seed size heterosis in cowpea (Vigna unguiculata L. WALP.). Ghana J. Sci. 12: 30-33.

Allard, R. W., 1960. Principles of plant breeding. John Wiley and Sons, Inc., New York.

ARYEETEY, A. M. \& E. LAING, 1973. Inheritance of yield components and their correlation with yield in cowpea (Vigna unguiculata L. WALP.). Euphytica 22: 386-392.

BritTingham, W. H., 1950. The inheritance of date of pod maturity, pod length, seed shape and seed size in the southern pea (Vigna sinensis). Proc. Am. Soc. Hort. Sci. 56: 381-388. 
CaVAlLi, L. L., 1952. An analysis of linkage in quantitative inheritance. In: E. C. R. Rieve \& C. H. WadDINGTON (Eds), Quantitative inheritance. pp. 135-144, HMSO, London.

Drabo, I., 1981. Inheritance in the cowpea Vigna unguiculata L. WALP. 100 seed weight, seed number per pod and seed coat characteristics. M. Phil. Thesis. University of Ibadan, Ibadan, Nigeria.

Drabo, I., T. A. O. Ladeinde, R. Redden \& J. B. Smithson, unpublished. Inheritance of seed size and seed number per pod in the cowpea (Vigna unguiculata L. WALP.).

JINKS, J. L. \& R. M. JonEs, 1978. Estimation of the components of heterosis. Genetics 43: 223-234.

LaWrence, M. J. \& J. L. Jinks, 1973. Quantitative genetics. In: P. H. ShePPard (Ed.), Practical genetics. pp. 88-129.

LELEJI, O., 1976. Inheritance of three agronomic characters in cowpea (Vigna unguiculata L.). Samaru Bulletin 252, Zaria, Nigeria.

MATHER, K., 1949. Biometrical genetics (1st Edn). Methuen, London.

MATHER, K. \& J. L. JiNKS, 1971. Biometrical genetics (2nd Edn). Chapman and Hall Ltd., London.

SENE, D., 1968. Héridité du poids de 100 graines chez Vigna unguiculata (L.) WALP. (Cowpea). Agron. Trop. 23: 1345-1351.

WARNER, D. J. \& S. HONMA, 1980. Inheritance of leaf geometry in cauliflower. J. Hered. 71: 105-109. 